\title{
Contribution to the Revision of the Senegalese Law on the Use of Sulfites for the Treatment of Crustaceans: the Case of Shrimp
}

\author{
Abdoulaye Diouf \\ Quai de Pêche mole 10 BP 50700 DAKAR
}

Tel: 221-775-662-077Ｅ-mail: ablaye7877@gmail.com

\begin{abstract}
Jean Fall (Corresponding author)
Institut Universitaire de Pêche et d'Aquaculture (IUPA) Université

Cheikh Anta Diop UCAD II batiment pédagogique/Rez de chaussée BP 5005 DAKAR

Tel: 221-779-564-339Ｅ-mail: kagoshima77@yahoo.com
\end{abstract}

\begin{abstract}
Nicolas Ayessou
Laboratoire d'Analyses et d'Essais/ Ecole Supérieure Polytechnique Université

Cheikh Anta Diop BP 5085 Dakar Fann
\end{abstract}

Tel: 221-825-0894

Mame Mor Ndour

Quai de Pêche mole 10 BP 50700 DAKAR

Tel: 221-775-342-283

Niokhor Diouf

Institut Universitaire de Pêche et d'Aquaculture (IUPA) Université

Cheikh Anta Diop UCAD II batiment pédagogique/Rez de chaussée BP 5005 DAKAR

Malang Seydi

Institut Universitaire de Pêche et d'Aquaculture (IUPA) Université Cheikh Anta Diop UCAD 
II batiment pédagogique/Rez de chaussée BP 5005 DAKAR

Received: May 28, 2014 Accepted: June 9, 2014

doi:10.5296/jbls.v7i1.8978

URL: http://dx.doi.org/10.5296/jbls.v7i1.8978

\begin{abstract}
Shrimp, by its considerable economic importance, is the second shellfish species exported in Senegal. Blackening of untreated sulfites shrimp causes discharges estimated at $10 \%$ of the total landed shrimp according to the shrimp processing plant companies. Health problems caused by handling and / or consumption of sulphites (asthmatic subjects) occured. The 2006-52 Directive of 5 July 2006 at Community level and Senegalese Decree No. 00493 of 11 February 2005 governed their use by rules. The Differences in the rules governing SO2 residues could cause Technical trade Barriers in international exchanges. In Senegal, the Competent Authority (CA), a part of its mission of monitoring and inspection of fish products, especially shrimp, cooperate with two chemistry laboratories for detecting residues of $\mathrm{SO} 2$. However, the differences noted on the results provided by these two laboratories (Lab1 and 2) make difficult interpretations. This study aims to remove existing ambiguities on the analyzes and interpretation of results regarding to national and community regulations. During the study, more investigations and analyzes of archival data, samples of untreated and treated shrimp sodium metabisulfite were analyzed respectively in the laboratory of the Division of Inspection and Control (DIC) to assess blackening and laboratories 1, 2 and 3 for the detection of residual sulphite in shrimp. Firstly, the results show that the shrimp processing and regulations governing the residual $\mathrm{SO} 2$ levels in their flesh can not be effective without taking account of their caliber, and secondly, that the divergence of results provided by the Labo- 1 and 2 is more methodological. Thus, the study calls for regulatory oversight in order to harmonize national and international regulations governing the residual SO2 levels in shrimp. It also recommends the creation of a common reference for the determination of residues of SO2 in the flesh of shrimp.
\end{abstract}

Keywords: Shrimp, Caliber, Metabisulfite, Regulations, Laboratories.

\title{
1. Introduction
}

Shrimp is the second exported species from Senegal after Octopus (DITP, 2010) base on its economic importance (9.83\% of fish and shellfish exports value in 2010), however, the exportation of shrimp at national and international level faces the enzymatic blackening (also called black spot or melanosis) due to the oxidation of tyrosine.

Black spots (melanosis) form on prawns and other shellfish within a few hours after harvest. This was once thought to be microbial but is now considered to be an enzymatic process (Lerner, 1953). After capture and death, these enzymes remain active and promote the development of black pigments on the shell. The reaction involves the oxidation of phenols to 
quinines by the enzyme polyphenol oxidase (PPO). Following this, a non-enzymatic polymerisation of quinines occurs. This leads to the formation of dark, high molecular weight melanins. In shellfish, PPO is involved in shellfish cuticle hardening and wound repair and indirectly in the immune system (Bartolo, 1995). Refrigeration alone does not prevent but only slows this process. Blackspot formation begins on the head of the animal and proceeds to the tail and legs with time.

Melanosis appears to occur independently of and prior to spoilage of the tail meat and as such is not a direct indicator of poor quality prawns. The melanosis results in a darkening that appears selectively to the junction of the carapace and body and at the junction of segments and finally the telson. The head becomes spongy; the shell softens and seems perforated with small holes. Enzymes such as peroxidases and hydrolases tyrosine, and copper ion, forming the haemocyanin of crustacean's blood, coenzyme a pyro-catecholase is responsible for the blackning. The way to prevent melanosis is the use of products with the effect of reducing the availability of oxygen and / or inhibition of the tyrosinase action. In addition, avoid too long exhibition of shrimp to light and high temperatures (Rakotomalala, 1998). The most currently used anti-oxidants are sulphites. However, the excess residues can cause health problems including asthmatic consumers. This explains, since 1950 (Fieger, 1951), the regulation on the residual sulfite in both raw and cooked shellfish and results:

The formation of black spot on shrimp is due to the polymerization of tyrosine to the dark pigment melanin. For years the shrimp industry has combatted this problem by dipping shrimp in a solution of metabisulfite.

This darkening of shrimp, although showing no toxicity to the consumer and hardly changing the flavor of shrimp has been serious sensory depreciation. This phenomenon significantly reduced their commercial value (Mc Evily et al, 1991), often resulting in discharge up to 10\% of the total weight of exports (Cathy, 2006).

At national level by Decree $N^{0} .00493$ of 11 February 2005 (MEM, 2005), which sets the amount of allowable residual sulfite in raw shellfish to $150 \mathrm{ppm}$ and $50 \mathrm{ppm}$ for cooked ones. These products landed or transshipped in the water bodies under Senegalese jurisdiction, are for local consumption or exportation.

At the international level of the European Union (EU) by Directive 2006-52-EC of 5 July 2006 amending Directive 95-02-EC of in accordance with size (less than $150 \mathrm{ppm}$ for prawns of large calibre and $300 \mathrm{ppm}$ maximum for those of small size).

That's why, at the national level and in the quality control of shrimp for compliance, the Competent Authority (CA) and industrial fishing is using the services of two local accredited laboratories named here Laboratory 1 and 2 for the determination of residual $\mathrm{SO}_{2}$.

However, two problems arise in the interpretation of results issued by these laboratories:

Problem 1: Given the difference in the regulations establishing the residual rate of bisulfite eligible, what should be the attitude of the CA when having a batch of shrimp that the rate of bisulfite exceeds the limit set at national level, but does not reach the level set by Directive 
2006-52-EC of 5 July $2006 ?$

Problem 2: In view of the difference between the results of analysis of the two laboratories (the results of laboratory 1 rarely exceed $20 \mathrm{ppm}$, while those of the Laboratory 2 are generally in the order of $150 \mathrm{ppm}$ on average), which lab results should then be formally adopted by the CA?

The main objective of the present study was to provide information necessary for the harmonization of national regulation on allowable residual sulfite in shrimp;

More particularly, this study aims to:

- ensure the existence of a correlation between the size of the shrimp and eligible bisulfite residual;

- propose a technique for efficient use of bisulfite treatment in shrimp;

-contribute to the establishment of a common referential for national laboratories for chemical analysis.

\section{Material and Methodes}

\subsection{Preparation of Treatment Solutions}

To conduct the experiments, we used two (02) processing solutions. A solution of $2.5 \%$, meeting the requirements of usage of the HQ Bacteriol $\mathrm{F}$ and another solution of $5 \%$ above the limit indicated on the product label. To comply with the soaking time, which is 5 minutes, the solution $2.5 \%$ was prepared in a first step, by dissolving $250 \mathrm{~g}$ of bisulfite in 10 liters of water. The same method was used for the preparation of the $5 \%$ solution $(500 \mathrm{~g}$ of bisulfite in 10 liters of water). For the measurement of 10 liters, a graduated cylinder two (02) liters was used as the bins do not have scales.

\subsection{Sampling Method}

After receiving shrimp from the SOPASEN fish and shellfish processing plant, they were stored at DIC for one week at temperatures $\leq-18^{\circ} \mathrm{C}$, to observe if in these conditions, shrimps will have black spots or not. Shrimps coming from Foundiougne were transported fresh to the laboratory. They were all treated after thawing and verification compliance caliber.

In the present experiment we have used fourteen (14) $\mathrm{kg}$ of shrimp divided in six (06) calibers $(1,3,5,6,7$ and 9):

Batch 1 consists of $2 \mathrm{~kg}$ of shrimp (all 6 sizes) untreated sulfite, representing the control group. ;

- Batch 2 consists of $6 \mathrm{~kg}$ of shrimp treated with sulfite at a concentration of $2.5 \%$ for 5 minutes;

- Batch 3 consists of $6 \mathrm{~kg}$ of shrimp treated with sulfite at a concentration of $5 \%$ for 5 minutes. 
Batch 2 and 3, after treatment, were divided into four (04) sub batch:

- Sub batch 1, consisting of 10 samples in which 5 treated with sulfite of $2.5 \%$ and 5 treated with sulfite of $5 \%$. These samples are then sent to the lab-1 for the determination of residual $\mathrm{SO} 2$.

- Sub batch 2, consisting of 10 samples in which 5 treated with sulfite of $2.5 \%$ and 5 treated with sulfite of $5 \%$. These samples are sent to the lab-2 for the same analyzes as the Labo- 1 .

- Sub batch 3 of the same composition as in batches 1 and 2 are then sent to the lab-3, for comparison with the results of lab-1 and 2 .

- Sub batch 4, consisting of 10 samples in which 5 are treated sulfite $2.5 \%$ and 5 treated with sulfite of $5 \%$. This sub batch 4 and the 6 samples of batch 1 were kept for organoleptic analysis at the DIC laboratory at temperatures $\leq-18^{\circ} \mathrm{C}$.

Each week, sensory analyzes were performed on these samples in order to assess the effectiveness of our treatment against the darkening, but also to evaluate the progression of melanosis in untreated sulfites shrimp.

These organoleptic analyzes based primarily on the appearance of blackening were made by a group of 04 panelists, all of whom are inspectors at DIC.

\subsection{Analytical Protocols}

The analytical protocols describe the method of determining the residual bisulfite. Analyses are performed at three (03) chemistry laboratories designed as Lab-1, Lab-2 and Lab-3. It should be noted that laboratories 1 and 3 are using the method of Monier-Williams, unlike Labo-2 use the Ripper modified by Marcille.

For assessment purposes of the results obtained by the two (02) reference laboratories in the field of chemical analysis will be compared with those of the third batch that were sent to the lab 3.

\subsection{Statistical Analysis}

The IBM ® SPSS 20 software was also used to see if (i) the analytical methods of laboratories has an influence on the results of $\mathrm{SO}_{2}$, (ii) if the caliber of the shrimp can impact on its content and $\mathrm{SO}_{2}$ (iii) if the type of treatment has an influence on the $\mathrm{SO}_{2}$ content.

For this kind of analysis, various statistical tests were used to compare the variances and mean values of $\mathrm{SO}_{2}$ obtained in these experiments, including the Levene test to test the homogeneity of variances, it is a prior to the application of ANOVA

If Levene's test is conclusive ( $p>0.05$ ), there is homogeneity of variance, the test of analysis of variance (ANOVA) will be use. This will show if the shrimp processing, caliber or the laboratory analysis can lead to differences in the content of residual $\mathrm{SO}_{2}$. The ANOVA also indicate whether induced differences are statistically significant or not.

If Levene's test is not conclusive $(\mathrm{p}<0.05)$, there is heterogeneity of variance, the test 


\section{Ml Macrothink}

Kruskal-Wallis will be used instead of the ANOVA. This is a nonparametric test that provides the same information as the one-way ANOVA

If both tests (ANOVA and Kruskal-Wallis) cannot show any difference, the Tukey test will be used. This test has the possibility to compare the modality of each factor taken 2 by 2 .

\section{Results}

\subsection{Results of Sensory Analysis}

Tables 1 and 2 show scores of melanosis of frozen shrimp treated with metabisulfite and held frozen fro 8 weeks. Sensory analyzes were performed on the batch of shrimp untreated Metabisulphite. Sensory analysis was conducted over eight week period with sampling days structured to observe prawns over the full period of shelf life. A numerical scoring system was developed for the purpose of this trial to allow a quantitative measure of quality.

\subsection{Evolution of Black Spot by Treatment}

Metabisulphite was trialled at 2.5\% and 5\% dipping for 5 minutes. Untreated prawns were used for reference and labelled 'control'. Organoleptic analysis focused on the development of melanosis were performed on samples of batch 1 and in batch 4 , kept at the DIC at $\mathrm{T} \leq$ $-18^{\circ} \mathrm{C}$ of storage. This sensory analysis was carried out each week by a group of four panelists,

Table 1. Visual scores of melanosis of frozen shrimp by treatment

\begin{tabular}{|l|l|l|l|l|l|l|l|l|}
\hline \multirow{2}{*}{ Type of treatment } & \multicolumn{7}{|c|}{ Weeks on ice } \\
\cline { 2 - 10 } & W1 & W2 & W 3 & W 4 & W 5 & W 6 & W 7 & W 8 \\
\hline Untreated & 0 & 0 & 0 & 1 & 1 & 2 & 2 & 3 \\
\hline $\mathrm{SO}_{2}$ à $2.5 \%$ & 0 & 0 & 0 & 0 & 0 & 0 & 0 & 0 \\
\hline $\mathrm{SO}_{2}$ à $5 \%$ & 0 & 0 & 0 & 0 & 0 & 0 & 0 & 0 \\
\hline
\end{tabular}

W: week

\begin{tabular}{|c|c|}
\hline 0 & Absence of mélanosis or bright appearance \\
\hline 1 & Occasional darkening $(<25 \%$ of the body) \\
\hline 2 & Slight darkening ( $50 \%$ the body) \\
\hline 3 & Blackening on all the body \\
\hline
\end{tabular}

Visual appearance in untreated shrimp declined consistently with initial blackening evident after only 4 week at temperatures $\leq-18$ storage, whereas those treated with sulfite, which until the eighth week of storage had no sign of melanosis.

\subsection{Evolution of Melanosis in Shrimp Untreated Metabusulfite by Caliber}

These sensory analyzes were performed as described above and according to caliber, to observe whether development of melanosis in shrimp depended on their size (cf table 2). 


\section{Macrothink}

Table 2. Visual scores of blackening of frozen shrimp untreated Meta busulfite by caliber

\begin{tabular}{|l|l|l|l|l|l|l|l|l|}
\hline \multirow{2}{*}{ Calibers } & \multicolumn{7}{|c|}{ Weeks on ice } \\
\cline { 2 - 10 } & W 1 & W 2 & W 3 & W 4 & W 5 & W 6 & W 7 & W 8 \\
\hline 1 & 0 & 0 & 0 & 0 & 0 & 0 & 0 & 1 \\
\hline 3 & 0 & 0 & 0 & 0 & 0 & 0 & 1 & 1 \\
\hline 5 & 0 & 0 & 0 & 0 & 0 & 1 & 2 & 2 \\
\hline 6 & 0 & 0 & 0 & 0 & 1 & 1 & 2 & 3 \\
\hline 7 & 0 & 0 & 0 & 1 & 1 & 2 & 3 & 3 \\
\hline 9 & 0 & 0 & 0 & 1 & 1 & 2 & 3 & 3 \\
\hline
\end{tabular}

$\mathrm{W}=$ week

\begin{tabular}{|l|}
\hline 0 \\
\hline 1 \\
\hline 2 \\
\hline 3 \\
\hline
\end{tabular}

Absence of melanosis or bright appearance

Occasional darkening $(<25 \%$ of the body)

Slight darkening (50\% the body)

Blackening on all the body

The results showed that from the fourth week, small sizes shrimp (7 and 9) begin to develop black spots (from the head). This phenomenon gradually increases and occupies the entire body from the 7th week. It occurs in the intermediate sizes (5 and 6) from the 5th and 6th week and finally appears on the big ones (1 and 3) after six weeks of storage at $\leq-18^{\circ} \mathrm{C}$. Shrimp caliber 1 have not completely filled until the end of the experiments ( 8 weeks). These results confirm that the small-sized shrimp are more sensitive to melanosis.

\subsection{Results of Chemical Analysis}

Tables 3, 4, 5 and 6 show residual levels of $\mathrm{SO}_{2}$ in shrimp treated with metabisulfite and held frozen fro 8 weeks.

Table 3. Mean values of $\mathrm{SO}_{2}(\mathrm{ppm})$ residues by laboratories

\begin{tabular}{|c|c|c|c|c|c|c|}
\hline \multirow[t]{2}{*}{ Calibers } & \multirow{2}{*}{$\begin{array}{ll}\text { Number } & \text { of } \\
\text { shrimp by Kg } & \end{array}$} & \multirow{2}{*}{$\begin{array}{l}\text { Concentration of } \\
\text { metabisulfite }\end{array}$} & \multicolumn{3}{|c|}{ Mean value of $\mathrm{SO}_{2} \mathrm{ppm}$ by laboratory } & \multirow{2}{*}{$\begin{array}{l}\text { Mean value of } \mathrm{SO}_{2} \mathrm{ppm} \\
\text { by caliber }\end{array}$} \\
\hline & & & Labo-1 & Labo-2 & Labo-3 & \\
\hline \multirow[b]{2}{*}{1} & \multirow[b]{2}{*}{$10-20$} & $2.5 \%$ & 1.28 & 6.28 & 7.03 & 4.86 \\
\hline & & $5 \%$ & 3.2 & 19.17 & 8.3 & 10.22 \\
\hline \multirow[b]{2}{*}{3} & \multirow[b]{2}{*}{$20-40$} & $2.5 \%$ & 15.98 & 0 & 8.95 & 8.31 \\
\hline & & $5 \%$ & 15.99 & 0 & 8.94 & 8.31 \\
\hline \multirow[b]{2}{*}{5} & \multirow[b]{2}{*}{$60-80$} & $2.5 \%$ & 18.53 & 184.16 & 16.61 & 73.10 \\
\hline & & $5 \%$ & 18.55 & 191.94 & 22.38 & 77.62 \\
\hline 6 & $80-100$ & $2.5 \%$ & 41.53 & 309.95 & 35.81 & 129.10 \\
\hline 7 & $100-120$ & $5 \%$ & 63.29 & 264.8 & 70.33 & 132.81 \\
\hline \multirow[b]{2}{*}{9} & \multirow[b]{2}{*}{$150-200$} & $2.5 \%$ & 170.74 & 316.09 & 141.89 & 209,57 \\
\hline & & $5 \%$ & 195.8 & 108.39 & 182.14 & 162.11 \\
\hline \multicolumn{3}{|c|}{ Mean value of $\mathrm{SO} 2 \mathrm{ppm}$ by laboratoy } & 54.489 & 140.078 & 50.238 & 81.60 \\
\hline
\end{tabular}


The results of table 3 revealed that:

- The mean values obtained by laboratories 1 and 3 were respectively 54 and 50 ppm $\mathrm{SO}_{2}$ residue, against $140 \mathrm{ppm} \mathrm{SO}_{2}$ obtained from the lab 2. This represents almost three times the concentration of $\mathrm{SO}_{2}$ residue that of Labo-1;

- The results obtained with dipping solutions 2.5 and $5 \%$ are not different for the given caliber, except caliber 9 where on all three laboratories, the level of $\mathrm{SO}_{2}$ residue are significantly different

Table 4. Mean values of $\mathrm{SO}_{2}(\mathrm{ppm})$ residues by caliber

\begin{tabular}{|l|l|l|l|l|l|}
\hline \multirow{2}{*}{ Calibers } & \multirow{2}{*}{$\begin{array}{c}\text { Number of shrimp per } \\
\text { Kg }\end{array}$} & \multicolumn{3}{|c|}{ Mean value of $\mathrm{SO}_{2} \mathrm{ppm}$ by } & \multicolumn{2}{c|}{ Mean value of $\mathrm{SO}_{2} \mathrm{ppm}_{\text {caliber }}$ by } \\
\cline { 3 - 6 } & \multicolumn{2}{|c|}{ Labo-1 } & Labo-2 & Labo-3 & \\
\hline 1 & $10-20$ & 2.24 & 12.73 & 7.66 & 7.54 \\
\hline 3 & $20-30$ & 15.98 & 0 & 8.94 & 8.31 \\
\hline 5 & $60-80$ & 18.54 & 188.05 & 19.5 & 75.36 \\
\hline 6 & $80-100$ & 41.53 & 309.95 & 35.81 & 129.10 \\
\hline 7 & $100-120$ & 63.29 & 264.8 & 70.33 & 132.81 \\
\hline 9 & $150-200$ & 183.27 & 212.24 & 162.02 & 185.84 \\
\hline $\begin{array}{l}\text { Mean value of } \mathrm{SO}_{2} \mathrm{ppm} \text { by } \\
\text { laboratoy }\end{array}$ & 54.14 & 140.07 & 50.71 & 107.79 \\
\hline
\end{tabular}

- The large shrimp (size 1 and 3) contained $\mathrm{SO}_{2}$ residue lesser than small shrimp (cf table 4)

Table 5. Appreciation of average $\mathrm{SO}_{2}$ residues according to national and international regulations

\begin{tabular}{|c|c|c|c|c|c|c|}
\hline \multirow[t]{2}{*}{ Calibers } & \multirow{2}{*}{$\begin{array}{l}\text { Number } \\
\text { of shrimp } \\
\text { per Kg }\end{array}$} & \multirow{2}{*}{$\begin{array}{l}\text { Mean } \\
\text { value of } \\
\mathrm{SO}_{2} \text { ppm } \\
\text { by caliber }\end{array}$} & \multirow[b]{2}{*}{$\begin{array}{l}\text { Maximum } \\
\text { permitted } \\
\text { residues by the } \\
\text { Senegalese } \\
\text { 0493Directive } \\
\text { 2005-11 }\end{array}$} & \multirow{2}{*}{$\begin{array}{l}\text { Maximum } \\
\text { permitted } \\
\text { residues by } \\
\text { the EU } \\
\text { Directive } \\
\text { 2006-52 EC }\end{array}$} & \multicolumn{2}{|c|}{ Appreciation } \\
\hline & & & & & $\begin{array}{l}\text { Senegalese } \\
\text { 0493Directive } \\
\text { 2005-11 }\end{array}$ & $\begin{array}{l}\text { EU } \\
\text { Directive } \\
\text { EC } \\
2006-52\end{array}$ \\
\hline 1 & $10-20$ & 7.54 & 150 & 150 & S & S \\
\hline 3 & $20-30$ & 8.31 & 150 & 150 & S & S \\
\hline 5 & $60-80$ & 75.36 & 150 & 150 & S & S \\
\hline 6 & 80-100 & 129.10 & 150 & 200 & $\mathrm{~S}$ & $\mathrm{~S}$ \\
\hline 7 & $100-120$ & 132.81 & 150 & 200 & S & S \\
\hline 9 & $150-200$ & 185.84 & 150 & 300 & NS & $S$ \\
\hline
\end{tabular}

$\mathrm{S}=$ Satisfactory, NS $=$ Non Satisfactory

Table 5 showed the level of $\mathrm{SO}_{2}$ residue of shrimp samples compared to international 
regulations (EC Directive 2006-52 dated 5 July 2006) and the Senegalese Decree 00493 of 11 February 2005.

The mean values of $\mathrm{SO}_{2}$ residue produced by the three (03) laboratories for each caliber were compared to the rate limits set by the two regulations. Levels of $\mathrm{SO}_{2}$ residue obtained for all calibers are satisfactory with regard to the European regulations on the residual $\mathrm{SO}_{2}$. But according to the Senegalese Decree regulating $\mathrm{SO}_{2}$ residues in crustaceans, the results of the caliber 9 consisting of 150-200 individuals / $\mathrm{kg}$ are not satisfactory, because they are in excess of the proposed limits of $150 \mathrm{ppm} \mathrm{SO}_{2}$.

Table 6. mean values of $\mathrm{SO}_{2}$ residues obtained from Labo-2 compared to national and international regulations

\begin{tabular}{|c|c|c|c|c|c|c|}
\hline \multirow[t]{2}{*}{ Calibers } & \multirow{2}{*}{$\begin{array}{l}\text { Number of } \\
\text { shrimp per } \\
\text { Kg }\end{array}$} & \multirow{2}{*}{$\begin{array}{l}\text { Mean value } \\
\text { of } \mathrm{SO}_{2} \mathrm{ppm} \\
\text { by caliber }\end{array}$} & \multirow{2}{*}{$\begin{array}{l}\text { Maximum } \\
\text { permitted } \\
\text { residues by the } \\
\text { Senegalese } \\
\text { 0493Directive } \\
\text { 2005-11 }\end{array}$} & \multirow{2}{*}{$\begin{array}{l}\text { Maximum } \\
\text { permitted } \\
\text { residues by the } \\
\text { EU Directive } \\
2006-52 \text { EC }\end{array}$} & \multicolumn{2}{|c|}{ Appreciation } \\
\hline & & & & & $\begin{array}{l}\text { Senegalese } \\
\text { 0493Directiv } \\
\text { e 2005-11 }\end{array}$ & $\begin{array}{l}\text { EU } \\
\text { Directive } \\
2006-52 \mathrm{EC}\end{array}$ \\
\hline 1 & $10-20$ & 12.73 & 150 & 150 & $S$ & $S$ \\
\hline 3 & $20-30$ & 0 & 150 & 150 & $S$ & $S$ \\
\hline 5 & $60-80$ & 188.05 & 150 & 150 & NS & $\mathrm{NS}$ \\
\hline 6 & $80-100$ & 309.95 & 150 & 200 & NS & $\mathrm{NS}$ \\
\hline 7 & $100-120$ & 264.8 & 150 & 200 & NS & NS \\
\hline 9 & $150-200$ & 212.24 & 150 & 300 & NS & $S$ \\
\hline
\end{tabular}

$\mathrm{S}=$ Satisfactory, NS $=$ Non Satisfactory

The results of lab-2 showed that more than $50 \%$ of the samples have concentrations of $\mathrm{SO}_{2}$ residue above the norm. These results concern the caliber 5, 6 and 7 on the basis of the two regulations, and caliber 9 according to Senegalese Decree 00493 of 11 February 2005 (see Table 6).

\subsection{Statistical Results}

The results of the tests showed that (i) the mean values of $\mathrm{SO}_{2}$ residue obtained from laboratories were highly significant different with $\mathrm{p}<0.05$, (ii) the mean values of $\mathrm{SO}_{2}$ residue were not different regarding to the concentration dipping solution of shrimp $(\mathrm{p} ;<0.05)$, (iii) the average $\mathrm{SO}_{2}$ also were highly significant different in relation to the size of shrimps with $\mathrm{p}<0,05$.

Base on the caliber, highly significant differences were observed between the sizes 1 and 9 and between sizes 3 and 9, according to the Kruskal-Wallis test. For other sizes, the difference was not significant $(\mathrm{p}>0.05)$.

From the statistical analysis, the mean level of $\mathrm{SO}_{2}$ in shrimp obtained in our experiments depends on the caliber and laboratory. 


\section{Discussion}

\subsection{Organoleptic Analysis}

Sensory tests on samples of batch 1 showed that untreated shrimp are blackning faster than those treated with sodium metabisulphite. This confirms the effectiveness of sodium metabisulphite in preventing the blackening of shrimp. It appeared that the small shrimp get blackspot faster than large ones.

In the present study, darkening appears in frozen shrimp untreated with metabisulphite from the fourth week of freezer storage $\left(\mathrm{T} \leq-18^{\circ} \mathrm{C}\right)$. These results are different from those of Stroud et al. 1982, for which untreated prawns can be kept on ice for 8-11 days after which they are considered inedible. Edmonds (2006) showed that untreated prawns start to develop melanotic blackening within 5 days of capture and reach an unacceptable quality after 6 days. Furthermore, Michelle and Parent (1973) reported that blackening occurs in shrimp untreated sulfite and kept in ice from the fourth day. Further, melanosis develops within 6-8 days (Greve, 1995).

This study revealed that shrimps treated with sulfite and stored frozen for eight weeks did not show any signs of blackening. This proves that the cold slows the enzymatic action of PPO in the blackened shrimp but cannot stop (Labuza and Schmidl, 1986). Contrary, Edmonds (2006) demonstrated that melanosis began on day 8 in shrimp treated with metabisulfite and stored in ice.

The mechanism of melanosis forms part of the animals immune and injury repair system. Sulphites have been found to irreversibly inhibit PPO (Ferrer et al., 1989; Lambrecht, 1995; Ricquebourgh et al., 1996). Sulphites have also been found to interact with formed quinones and change coloured orthoquinones back to colourless and less reactive diphenols (Ricquebourgh et al., 1996).

The present study show that the two batches of shrimp treated with sodium metabisulfite at concentrations of 2.5 and $5 \%$ for 5 minutes did not show signs of darkening to the eighth week, this showed that these two treatment options are effective in preventing the blackening. Contrary, metabisulphite was trialled at 2.5\%, dipping for 3 minutes and 5\% for 10 minutes. The results revealed that the visual appearance in untreated prawns declined consistently with initial blackening evident after only 4 days on ice. By day 14 blackening was evident in all prawns. Metabisulphite at $5 \%$ is more effective than $2.5 \%$ for maintaining prawn appearance (Edmonds, 2006). Metabisulphite 5\% was found to extend prawn shelf life and prevent blackspot formation for up to 7 days. This was found to decrease when used at lower concentrations.

Guidelines for correct dipping procedure include a 2 minutes dip at $1.25 \%$ by the Danish Ministry of Fisheries (Bartolo, 1995) and a 3 minutes dip at 2.5\% (BIM and Seafood Scotland). Despite this, many vessels routinely dip for 10 minutes at $5 \%$ highlighting the lack of continuity throughout industry. Dipping in an aqueous bath is the most common method for treating large numbers of prawns at a given concentration. It has been suggested that some onboard practices involve the application of metabisulphite 'dry' to the top layer of a full, 
iced box of prawns.

Other sulphite based treatments showed similar performance to 5\% metabisulphite. Montero et al. (2004) reported that deepwater pink shrimp (Parapenaeus longirostris) were highly sensitive to melanosis, and that there was an increase in the inhibition of melanosis after the shrimp were treated with increasing concentrations of 4-hexylresorcinol. These investigators found that a concentration of $0.25 \%$ 4-hexylresorcinol was effective at extending the shelf life of this species for 1 week.

It has been shown that 4-hexylresorcinol is a competitive inhibitor (Jimenez and Garcia-Carmona, 1997) and it has widely been described as a good alternative to the use of sulphites by dipping (Frankos et al., 1991; McEvily et al., 1991; Iyengar and McEvily, 1992; Otwell et al., 1992; Guandalini et al., 1998). The melanosis-inhibiting effect of 4-hexylresorcinol accompanied by several organic acids and chelating agents, has also been reported in prawns (Montero et al., 2001).

Adachi et al. (2001) have also reported a significant and rapid development of black spots in Kuruma prawn after thawing. Shrimp treated with 4-hexylresorcinol showed the best appearance during conservation, with only a slight melanosis over a minimum of 8 days.

A comparable visual performance between the three sulphite (Xyrex, EVerfresh and Aquabon) based treatments was conducted. All showed good melanosis prevention to day 7 / 8. Xyrex was the most effective non-sulphite based treatment for maintaining appearance. Only limited blackening was observed and these samples were frequently the best looking of all treatments throughout the trial. Everfresh treated samples showed good appearance to day 10, with overall melanosis prevention comparable to sulphite based treatments. Some melanosis prevention was evident in samples treated with Aquabon. The two most effective non-sulphite treatments were Everfresh and Xyrex Prawnfresh. The latter was found to have the greatest effect on maintaining quality and extended blackspot prevention to 10 days.

Prawns showed better appearance than untreated samples although had significantly reduced shelf life to preceding treatments. Soft acid, citric acid and ascorbic acid did not show any control of melanosis. Despite the limited sample size it is apparent that citric and ascorbic acid had a negative effect on freshness. Total blackening was evident after 10 days with both treatments (Edmonds, 2006).

\subsection{Chemical Analysis}

The average content of sulfur dioxide $\left(\mathrm{SO}_{2}\right)$, null in the control batch is higher in batch 3 (shrimp treated with metabisulphite 5\%) than in batch 2 (shrimp treated with metabisulphite $2.5 \%$ ). These results are in line with those of Edmonds (2006). This author revealed that metabisulphite $2.5 \%$ gave $\mathrm{SO}_{2}$ residues of between 37 to $61 \mathrm{ppm}$, however at $5 \%$ these increased to a maximum of $171 \mathrm{ppm}$ (it is likely that the values of 557 and 755 have been erroneously recorded or were the result of sample contamination).

The small shrimp present higher concentrations of $\mathrm{SO}_{2}$ than those of large ones. This tendency of small shrimp to darken and absorb $\mathrm{SO}_{2}$ faster than large shrimp, suggests two 
hypotheses: (i) small individuals have their shell more fragile and permeable to sulfites and oxygen than large (more rigid and waterproof shell), (ii) the shells of small individuals contains more tyrosine or polyphenol oxidase than larger individuals.

Michel Parent (1973), argue that the content of $\mathrm{SO}_{2}$, much higher in small shrimp is due in part to the surface / weight relationship. This relationship is reflected in some living organims, through the acquisition during the growth of a kind of resistance phenomena they were vulnerable at birth.

The results of chemical analyzes, seen from the regulatory angle, gives an overall assessment of the acceptability of shrimp. The interpretation of the results provided by the three laboratories, under the regulations, shows that only shrimp of caliber 9 (150-200 shrimps / $\mathrm{kg}$ ), have rates above the limit set at the national level is $150 \mathrm{ppm}$. Adverse results have been obtained by authors. Bailey and Fieger (1955) reported residual levels of approximately 30 ppm $\mathrm{SO}_{2}$ in shrimp stored for 10 days in $0.1 \% \mathrm{NaHSO}_{3}$ ice. Wood et al.(1976) dipped shrimp according to the codex conditions and reproted a decrease from $218 \mathrm{ppm}$ to $5 \mathrm{ppm}$ in peeled raw meat after 11 days storage on ice. After 15 days storage, Wengartner et al. (1977) found a decrease from $65 \mathrm{ppm}$ to $5 \mathrm{ppm}$ residual $\mathrm{SO}_{2}$ on the peeled muscle of shrimp dipped for 5 min in $1.25 \% \mathrm{NaHSO}_{3}$.

The other observation is that the results of lab-2 are widely dispersed and do not follow a certain consistency, like the Lab-1 and 3. That is to say that the levels of $\mathrm{SO}_{2}$ small shrimp are higher than large ones; levels of $\mathrm{SO}_{2}$ shrimp dipped in a solution of 5\% metabisulphite are higher than those of shrimp processed in 2.5\%, similar to Michel Parent (1973) and Edmonds (2006) results.

Laboratory results indicate that prawns treated with 5\% metabisulphite contained the highest sulphite residues, often above the maximum permitted level of $150 \mathrm{ppm}$. Prawns with high sulphite residue were found to have the least favourable flavour.

There is no doubt that metabisulphite, applied in solution, delays blackspot formation. This has greater effect at high concentrations (trialled to 5\%) although natural shell pigmentation is reduced through bleaching.

\subsection{Statistical Analysis}

Nevertheless, the results obtained by the control laboratory (Lab-3) with no significant difference with those of lab-1 at the 5\% level according to ANOVA, in addition to the fact that these results support those of Michel Parent (1973) and Edmonds (2006), lead us to take the results of lab-1 with fewer deductions than the lab-2

Statistical analyzes show that the overall content of residual $\mathrm{SO}_{2}$ in the shrimp meat, ranging from insignificant as a function of the concentration of the solution sulfitation $(2.5 \%$ or $5 \%)$ is closely related to the size of the shrimp and the laboratory that performed the analysis of the products.

These results confirm on one hand, the need to spread the residual $\mathrm{SO}_{2}$ depending on the size, as is the case in Directive 2006/ 52 of 5 July 2006 and secondly, that the difference noted 
between the results obtained by the two laboratories was not related to the origin of products, but rather to internal problems to analytical methods. The differences could be due to a difference in analytical methods, materials, reagents, expertise or competence of the workforce.

But unlike the methods of analysis seems to be more plausible. Sofar, the Labo-1 uses the modified Monier-Williams, quoted in the AOAC as a reference for research and Lab S02-2 Quick Method Ripper amended by Marcille. However, the lab-3 using the same method as the Lab-1, produced similar results. The average SO2 in lab-1 and 3 have no significant difference, DNS ( $\mathrm{p}>0.05)$.

\section{Conclusion and Recommandations}

Metabisulfite treatment cant prevent melanotic blackening. This is an inevitable part of the spoiling process with blackspots appearing in time with all treatments. At best, melanotic blackening can be delayed.

As most of the additives, the use of sulphites is governed by regulations. It is internationally GSFA at EEC level of 2006-52-EC Directive on 5 July 2006 and at the national level of the order Senegalese 00493 of 11 February 2005. However the differences noted between the regulations (national and international) have often caused difficulties of implementation by CA.

To this is added the recurrent problem due to the difference observed between the results produced by the two (02) laboratory chemical analysis approved by the CA.

The results of the case study conducted to compare laboratories and residual sulphite levels in shrimp reveal that (i) the residual sulphite content in shrimp is inversely proportional to their size, (ii) the heterogeneity of laboratory results is more related to a difference of analysis methods used, (iii) sulfitation is not well controlled in the fishing industry.

Due to the scale of the trial it was not possible to replicate within sample batches leaving results of limited statistical robustness. However this trial is of use as an initial appraisal of treatments and indicates a number of viable competitors to sodium metabisulphite for extending effective shelf life of prawns.

In the light of this study, we recommend to:

- conduct a legal and normative watch, harmonizing the Senegalese 00493Decree 2005-11, with the EU Directive 2006-52 EC;

- equip the AC laboratory's to carry out official analyzes;

- continue this study to determine the origin of the difference between the results obtained by both laboratories for chemistry, comparing them to other laboratories in the subregion or European;

- establish adequate traceability, taking into account the amounts of additives used relative to the output;

- work for the establishment of a network of inter-comparison of chemical laboratories. This process will first go through collaboration with laboratories in other countries of 


\section{Macrothink}

Journal of Biology and Life Science

ISSN 2157-6076

2016, Vol. 7, No. 1

the sub region. Indeed, it takes at least eight laboratories for the results of the network are recognized as an international reference (Max Feinberg, 1999);

- encourage the use of alternatives to sulfites, such as EverFresh the Xyrex, products having obtained good results in the fight against melanosis;

\section{References}

AOAC. (1980). Official methods of analysis, $13^{\text {th }}$ ed. Association of Official Analytical Chemists. Washington, D.C, pp.296.

Cathy P. (2006). The use of EverFresh ${ }^{\circledR}$ for preventing melanosis on shrimp and other crustaceans. In: Seafood Science and Technology Conference, 16p.

DITP. (2010). Rapport statistique des exportations des produits halieutiques, pp.12-22.

Edmonds M. (2006). Sodium metabisulphite alternatives. Technology implementation department. SR83. 19p.

Feinberg M. (1999). Assurance qualité dans les laboratoires agroalimentaires et pharmaceutiques. pp.127-142.

Fieger E. A. (1951). Cause and prevention of black spot on shrimp. Ice Refrig.120:49.

Labuza, T. P., \& Schmidl, M. K., (1986). Advances in the control of browning reactions in foods. In: Fennema, O. (Ed.) Role of Chemistry in the Quality of Processed Foods. Food and Nutrition Press, Westport, CT, pp. 66-74.

Mc-Evily A. J., Yengar R., Otwell S. (1991). Sulfite alternative prevents shrimp melanosis. Fd Technol., 822-826.

MEM, (2005). Arrêté $\mathrm{n}^{\circ} 0493 / \mathrm{MEM} / \mathrm{DITP} / \mathrm{BCQ}$ du 11 février 2005, fixant les plans d'échantillonnage, les méthodes d'analyses et les niveaux à respecter pour les sulfites des produits de la pêche et de l'aquaculture.

Michelle C., Parent B. (1973). Essais de traitement des langoustines par des agents conservateurs.

Rakotomalala H., (1998). Mise en place d'un système d'autocontrôle selon la démarche HACCP dans une usine de traitement de crevettes. Cas de la Société Les Pêcheries du Menabe; Mémoire de fin d'étude ESSA-Département IAA, 168 p.

Adachi, K., Hirata, T., Nagai, K., \& Sakaguchi, M. (2001). Hemocyanin a most likely inducer of black spots in kuruma prawn (Penaeus japonicus) during storage. Journal of Food Science, 66, 1130-1136. http://dx.doi.org/10.1111/j.1365-2621.2001.tb16093.x

Ferrer, O. B., Koburguer, J. A., Otwell, W. S., Gleeson, R. A., Simpson, B. K., \& Marshall, M. (1989). Phenoloxidase from the cuticle of Florida spiny lobster (Palinurus argus): mode of activation and characterization. Journal of Food Science, 54, 63-67. http://dx.doi.org/10.1111/j.1365-2621.1989.tb08568.x

Frankos, V. H., Schmidtt, D. F., Haws, L. C. et al. (1991). Generally Recognised As Safe 
(GRAS) evaluation of 4-hexylresorcinol for use as a processing aid for prevention of melanosis in shrimp. Regulatory Toxicology and Pharmacology, 14, 202-212. http://dx.doi.org/10.1016/0273-2300(91)90007-I

Guandalini, E., Ioppolo, A., Mantovani, A., Staachini, P., \& Giovannini, C. (1998). 4-hexylresorcinol as inhibitor of shrimp melanosis: efficacy and residues studies; evaluation of possible toxic effect in a human intestinal in vitro model (Caco-2); preliminary safety assessment. Food Additives and Contaminants, 15, 171-180. http://dx.doi.org/10.1080/02652039809374627

Iyengar, R., \& McEvily, A. J. (1992). Anti-browning agents: alternatives to the use of sulfites in foods. Trends in Food Science and Technology, 3, 60-64. http://dx.doi.org/10.1016/0924-2244(92)90131-F

Jiménez, M., \& Garcia-Carmona, F. (1997). 4-substituted resorcinols (sulfite alternatives) as slow-binding inhibitors of tyrosinase catecholase activity. Journal of Agricultural and Food Chemistry, 45, 2061-2065. http://dx.doi.org/10.1021/jf960810n

Lambrecht, H. S. (1995). Sulfite substitutes for the prevention of enzymatic browning in foods. In: Enzymatic Browning and its Prevention (edited by C.Y. Lee \& J.R. Whitaker). Pp. 313-323. Washington, DC: American Chemical Society. http://dx.doi.org/10.1021/bk-1995-0600.ch024

McEvily, A. J., Iyengar, R., \& Otwell, S. (1991). Sulphite alternative prevents shrimp melanosis. Food Technology, September, 80-86.

Montero,P., Lopez-Caballero, M. E., \& Perez-Mateos, M. (2001).The effect of inhibitors and high pressure treatment to prevent melanosis and microbial growth on chilled prawns (Penaeus japonicus). Journal of Food Science, 66, 1201-1206. http://dx.doi.org/10.1111/j.1365-2621.2001.tb16105.x

Montero, P., Martınez-Alvarez, O., \& Go mez-Guillen, M. C. (2004). Effectiveness of onboard application of 4-hexylresorcinol in inhibit- ing melanosis in shrimp (Parapenaeus longirostris). Journal of Food Science, 68, 643-647. http://dx.doi.org/10.1111/j.1365-2621.2004.tb09913.x

Otwell, W. S., Iyengar, R., \& McEvily, A. J. (1992). Inhibition of shrimp melanosis by 4-hexylresorcinol. Journal of Aquatic Food Product Technology, 1, 53-65. http://dx.doi.org/10.1300/J030v01n01_07

Ricquebourgh, S. L., Robert-Da Silva, C. M. F., Rouch, C. C., \& Cadet, F. R. (1996). Theoretical support for a conformational change of polyphenol oxidase induced by metabisulfite. Journal of Agricultural and Food Chemistry, 44, 3457-3460. http://dx.doi.org/10.1021/jf960012x

Maria Elvira López-Caballero, ${ }^{*}$ Oscar Martınez-Alvarez, Maria del Carmea Gomez-Guillen \& Pilar Montero 2007, Quality of thawed deepwater pink shrimp (Parapenaeus longirostris) treated with melanosis-inhibiting formulations during chilled storage, International Journal 


\section{Macrothink}

of Food Science and Technology, 42, 1029-1038

\section{Copyright Disclaimer}

Copyright for this article is retained by the author(s), with first publication rights granted to the journal.

This is an open-access article distributed under the terms and conditions of the Creative Commons Attribution license (http://creativecommons.org/licenses/by/3.0/). 